\title{
Editorial: ‘Quality' and Curriculum
}

New Zealand Journal of Teachers' Work, Volume 11, Issue 2, 157-158, 2014

\section{NESTA DEVINE \& LEON BENADE \\ Co-Editors}

In their final editorial, John O'Neill and Paul Adams lamented for the loss (as they saw it) of hope and optimism in the future of public education in New Zealand. As the incoming editors, this seems a particularly severe mood with which to begin our task. They made, nevertheless, some telling points, in particular the drive to the creation of 'idiot-proof' criteria of 'effective teaching', adherence to which will, seemingly, guarantee 'quality teaching'. How ironic then, that during the period in which we were amassing and editing this issue of the journal, the New Zealand Herald broke with a story which 'exposed' the quality of (some) early childhood education facilities (Johnston, "Early childcare services red-flagged", 2015). Johnstone's article pre-figured the actual Education Review Office (ERO) report, released just last week (ERO, 2015). The Report is much more temperate than the New Zealand Herald story, as might be expected, but nonetheless it did point out that the 'quality' of the education available to infants and toddlers varied across institutions, particularly with regard to the development of communication, (that is in the area of language and social skills), and in encouraging 'exploration' which is to say, self-confidence, and interest in the world-the fore runners of success and science, among other things.

We asked for a response from some eminent early childhood academics and have included those responses here. They include thoughtful consideration of what constitutes 'quality', what constitutes good teacher education, and of the always-fragile tension between early childhood education and the parents who entrust their children to it, and the economic considerations that make this entrustment less about choice than about necessity.

The ERO report does the professional area a favour by addressing two areas in which it needs to pay more attention, and gives them a 'checklist' by which to measure their own success in doing so.

At the same time it draws attention to the relative advantage of babies over toddlers in terms of care, safety, warm relationships. We would suggest that this decline in the warmth of the relationships with which children are embraced in education continues, even accelerates, throughout their school years. Bill Ussher and Anthony Fisher draw attention to the narrowing of the school curriculum in response to government policy and principles, and the role of ERO in-quite possibly inadvertently-encouraging the decline of the implementation of the 2006 curriculum by emphasising, and rewarding, the governmentally approved tropes of 'quality'-literacy, numeracy and 'ICT', variously interpreted.

The question should be asked: why do the values, which ERO clearly understands in relation to ECE, not appear in its evaluation of services for older children? Why are schools not critiqued for their lack of interest in the breadth of curricular possibilities, the elements of care and safety, the depth of 
communication and encouragement of exploration? Or, in keeping with neoliberal 'choice' and 'autonomy', is it for individual schools and teachers to implement interventions, such as the mindfulness programmes referred to by Ross Bernay and Grant Rix?

The theme of adding value to the curriculum is uppermost in the minds of those who engage as specialist contractors in the area of outdoor education, such as Alan Haslip, Jo Straker and Sarah English. Given the risks sometimes involved in outdoor education, this is a curriculum area that is increasingly difficult to maintain, a task complicated by teachers who do not adequately communicate their desired outcomes or values to contractors, as suggested by these authors.

The articles assembled under this issue have very close links to curriculum concerns, and those written by Mortlock, Green, Shuker and Johnstone on one hand, and Charteris on the other, are no exception. They each address, from their respective perspectives, the challenge of addressing the notion of dispositions for lifelong learning. It may well be, that as Charteris suggests, the assumptions of educators and regulators about the fixed and permanent nature of the 'backpack' with which we try to provide students in their schooling years is an inadequate way to conceptualise the changing nature and needs of a population that is territorially, economically, intellectually and psychologically more mobile than is assumed.

\section{Acknowledgements}

As the new editors, we have had to deal with some significant teething problems in the production process associated with this, our first issue. We acknowledge with thanks, both the patience of the authors, and the willing support of the reviewers who have ensured that our first issue provides a promising start. This issue provides a range of excellent, relevant, and provocative papers which we hope will provide challenging material for thought on Teachers' Work in New Zealand now.

\section{REFERENCES}

Education Review Office (ERO). 2015. Infants and toddlers: competent and confident communicators and explorers. Retrieved from http://www.ero.govt.nz/National-Reports/Infants-and-toddlers-competentand-confident-communicators-and-explorers-June-2015/National-ReportSummary

Johnstone, K. Early childcare services red-flagged. (2015, April 20). New Zeaand Herald. Retrieved from http://www.nzherald.co.nz/nz/news/article.cfm?c_id=1\&objectid=1143523 5\&ref=NZH_FBpage 